\title{
Meningkatkan Kompentensi Pengelola Wisata Desa melalui Penyuluhan Pelayanan Prima
}

\author{
Hary Hermawan \\ Sekolah Tinggi Pariwisata AMPTA,Yogyakarta, Indonesia, Email: haryhermawan8@gmail.com
}

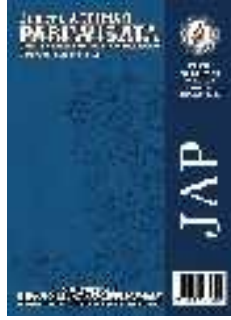

\begin{tabular}{|c|c|}
\hline \multicolumn{2}{|c|}{ Informasi artikel } \\
\hline $\begin{array}{l}\text { Sejarah } \\
\text { artikel }\end{array}$ & \\
\hline Diterima & : 5 Januari 2019 \\
\hline Revisi & : 1 April 2019 \\
\hline Dipublikasikan & : 15 Januari 2020 \\
\hline $\begin{array}{l}\text { Kata kunci: } \\
\text { Pelayanan Prima } \\
\text { Pengabdiam Mas } \\
\text { Penyuluhan } \\
\text { Pariwisata }\end{array}$ & yarakat \\
\hline
\end{tabular}

\begin{abstract}
ABSTRAK
Saat ini kepuasan pelanggan merupakan kunci dalam memenangkan bisnis pariwisata. Tetapi pada kenyataan masih banyak pelaku industry ariwisata yang tidak memahaminya. Fenomena menunjukan masih banyak pelaku bisnsi pariwisata yang berbuat curang seperti penarikan harga yang terlalu tinggi demi keuntungan jangka pendek. Oleh karena itu, sangat penting untuk melakukan penyuluhan tentang bagaimana mengelola layanan pariwisata yang baik dengan pendekatan 5 dimensi ke pelayanan prima, terutama untuk destinasi wisata prospektif yang akan dikembangkan. Untuk mengetahui efektivitas program ini, analisis deskriptif telah dilakukan. Hasil tes menunjukkan ada pemahaman peserta tentang pelayanan prima setelah konseling.
\end{abstract}

Keywords:

Service excellent

Community service

Counseling

Tourism

\section{ABSTRACT}

Increasing Competency of Village Tourism Managers through

Counseling Prime Services

Customer satisfaction is the key to winning business competition today, including the tourism business. But in the field there are still many tourism people who still ignore this at this time. A phenomenon that is often encountered is cheating in business, attracting prices too high to achieve big profits in a short time. Therefore, it is very important to do counseling on how to manage good tourism services with a 5dimensional approach to excellent service, especially for prospective tourism destinations that will develop. To find out the effectiveness of this program, a descriptive analysis has been carried out. The test results indicate there is an understanding of participants about excellent service after counseling.

Copyright @2020 Sekolah Tinggi Pariwisata AMPTA. All Right Reserved

\section{Pendahuluan}

Kepuasan pelanggan merupakan kunci dalam memenangkan persaingan bisnis saat ini, termasuk pada bisnis pariwisata. Kepuasan pelanggan juga telah lama menjadi perhatian wirausahawan, peneliti, dan para praktisi ahli pemasaran (Edvardsson dkk., 2005). Akan tetapi, fakta di lapangan masih banyak ditemui perilaku oknum-oknum pariwisata yang masih mengabaikan prinsip kepuasan pelanggan dalam operasi bisnisnya.

Fenomena yang sering ditemui adalah perbuatan curang dalam bisnis, beberapa contoh kasus yang cukup menyita perhatian diantaranya : Kasus pertama, ditemukanya harga-hraga menu makanan di restoran yang tidak transparan, serta tidak sesuainya harga menu sebenarnya dengan harga yang ditampilkan di beberapa restoran, salah satu kasus terakhir yang sempat viral terjadi di Malioboro Yogyakarta (Sadnyari, 2017). Kasus kedua, maraknya tarif parkir dengan harga yang sangat tidak masuk akal dilakukan oleh beberapa oknum pengelola parkir wisata di Patai Anyer, Pantai Carita dan Pantai Karang Bolong di Provinsi Banten (Ralemug, 2018). Kasus ketiga, maraknya oknum pariwisata di yang memaksa wisatawan untuk memanfaatkan jasa yang ditawarkan, sebagai contoh yang terjadi di kawasan Pura Agung Besakih Bali. Banyak wisatawan yang merasa tidak nyaman dengan pedagang acung yang terus mengejar pengunjung. Pemaksaan untuk transportasi ojek dan pemaksaan membeli canang (Buletin Dewata, 2017). Umumnya, berbagai perilaku buruk para oknum di berbagai destinasi tersebut hanya didasari oleh motivasi memperoleh keuntungan yang besar dalam waktu yang singkat, 
tanpa mau peduli tantang kenyamanan dan kepuasan wisatawan selama berwisata, termasuk tidak peduli terhadap kelangsungan destinasi wisatanya dalam jangka panjang.

Kepuasan pelanggan, yang selanjutnya lebih tepat disebut sebagai kepuasan wisatawan dalam konteks pariwisata, hanya dapat diwujudkan dengan cara memahami kemauan wisatawan dengan akurat atau sering disebut sebagai focus customer (Yang \& Zhang, 2018).Focus customer dalam pariwisata dapat diartikan secara bebas sebagai kegiatan memahami apa saja kebutuhan dan keinginan wisatawan selama berwisata, serta bagaimana cara yang tepat untuk melayaninya.

Daya tarik wisata suatu destinasi memang telah terbukti menjadi faktor dominan yang menentukan kepuasan wisatawan (Hermawan, 2017). Akan tetapi, tanpa pelayanan yang baik, serta didukung keramah-tamahanan tuan rumah selaku pengelola, pariwisata tidak lebih dari benda mati. Pelayanan seara sederhana dapat diartikan sebagai suatu kegiatan yang diperuntukan kepada pelanggan untuk memberi kepuasan melalui pelayanan yang dapat memenuhi kebutuhan dan keinginan pelanggan. Pelayanan dapat didefinisikan sebagai segala bentuk kegiatan atau manfaat yang dapat diberikan satu pihak kepada pihak lainya tanpa menimbulkan perpindahan suatu kepemilikan fisik (Kotler \& Armstrong, 2012).

Berdasarkan definisi ahli diatas, dapat dirangkup konsep baru pelayanan yang disesuaikan dengan bidang pariwisata, yaitu pelayanan sebagai segala bentuk kegiatan yang ditawarkan penyedia jasa wisata kepada wisatawan, guna memenuhi kebutuhan dan keinginanya selama berwisata, tanpa menimbulkan perpindahan kepemilikan yang berwujud fisik.

Pelayanan merupakan aspek mendasar serta motivasi utama dalam menjalankan bisnis pariwisata dan keramah-tamahan (hospitality)(Hermawan, dkk., 2018). Dalam pelayanan pariwisata, kepuasan dan kebahagiaan pelanggan lebih penting daripada kepuasan pimpinan. Karena pelangganlah yang akan membuat usaha hospitality dapat terus hidup dan berjalan (Sulastiyono, 2011)

Konsep pelayanan prima atau pelayanan terbaik sampai saat ini masih dianggap sebagai salah satu solusi dalam pelayanan jasa yang mampu memenuhi kebutuhan dan keinginan pelanggan secara umum. Hasil penelitian para ahli yang telah membuktikan pentingnya pengelolaan pelayanan prima. Penerapan pelayanan prima terbukti sangat penting guna memenangkan persaingan bisnis (Al Rasyid, 2017). Penalitian lain mengatakan bahwa dalam industri pariwisata, kepuasan wisatawan sangat ditentukan oleh faktor pelayanan prima (González, Comesaña, \& Brea, 2007)

Pelanggan hanya menilai kualitas pelayanan pariwisata dengan menggunakan pendekatan lima dimensi pelayanan sebagai tolok ukur penilaian, yaitu:

1. Realibilitas atau kehandalan(realibility), adalah kemampuan untuk memberikan secara tepat dan benar sesuai jenis pelayanan yang sebelumnya telah dijanjikan kepada pelanggan.

2. Responsif atau daya tanggap(Responsiveness), yaitu kesadaran atau keinginan untuk bertindak capat dalam membantu pelanggan dan memberikan pelayanan tepat waktu.

3. Kepastian atau jaminan (Assurance), adalah pengetahuan dan kesopan santunan serta kepercayaan diri pegawai. Dimensi assurance memiliki ciri-ciri: kompetensi untuk memberikan pelayanan dan memiliki sifat respek kepada tamu.

4. Empati (Empathy), memberikan perhatian individu kepada tamu secara khusus. Dimensi empati memiliki ciri-ciri : kemauan untuk melakukan pendekatan, memberikan perlindungan dan usaha untuk mengerti keinginan, kebutuhan dan perasaan tamu.

5. Nyata atau bukti langsung(Tangibles), yaitu sesuatu yang nampak atau yang nyata, contonya: penampilan para pegawai yang rapi, fasilitas peralatan yang bersih dan higyene, peralatan fasilitas penunjang yang berfungsi baik dan lain sebagainya (Hermawan dkk., 2018; Jaya, W \& Rismayanti, 2017; dan Wilson dkk., 2012).

Kelima dimensi pelayanan diatas terbukti sangat memegang peranan penting dalam memberikan pelayanan prima terhadap konsumen (Wahyuni, \& Rismayanti, 2017)

Lima dimensi pelayanan prima diatas selanjutnya dalam artikel ini disebut sebagai objek penelitian, atau variabel atau fenomena yang diamati dan dinilai selama proses penyelidikan berlangsung.

Mengingat pentingnya pelayanan prima dalam operasional bisnis pariwisata, maka artikel ini akan membahas bagaimana penyuluhan dapat meningkatkan pemahaman pelayanan prima kepada masyarakat desa selaku pengelola wisata desa. Penyuluhan dalam Kamus Besar Bahasa Indonesia dapat berarti penerangan ("Kamus Besar Bahasa Indonesia (KBBI)," 2018). Atau membuat segalanya menjadi jelas. Sedangkan definisi lain dari penyuluhan adalah bekerja penuh komitmen dan kreativitas 
serta memiliki semangat tinggi membantu masyarakat belajar membebaskan dirinya dari kemiskinan dan keterbelakangan untuk menuju kehidupan yang lebih baik (Karsidi, 2001).

Penyuluhan pada dasarnya memiliki fungsi untuk meningkatkan kualitas sumber daya manusia (SDM), terutama dalam membentuk dan mengubah perilaku masyarakat untuk mencapai taraf hidup yang lebih berkualitas. Pembentukan dan perubahan perilaku tersebut, baik dalam dimensi seluruh aspek kehidupan manusia (Karsidi, 2001).

Dalam praktiknya ,penyuluhan memiliki beragam variasi metode.Penyuluhan dimaksud dalam artikel ini adalah kegiatan memberikan pemahaman kepada masyarakat melalui metode presentasi materi dengan cara ceramah dan tatap muka antara narasumber dengan partisipan. Narasumber mempresentasikan materi menggunakan media slide power point, dibantu alat bantu LCD proyektor, sedangkan partisipan mendengarkan ceramah hingga selesai. Waktu presentasi yang dialokasikan selama 30 menit.Materi yang disampaikan meliputi 5 dimensi pelayanan prima dalam bidang kepariwisataan, meliputi : Bukti langsung (tangibles), kehandalan (reliability), daya tanggap (responsiveness), jaminan (assurance), dan empati (emphaty).

Penyuluhan pelayanan prima dianggap penting bagi pengelola wisata desa di Dusun Bulu yang masih dalam tahap rintisan, agar pengelolaan wisata yang akan dilakukan betul-betul menjadi destinasi wisata yang memusakan wisatawan yang mewisatainya. Kegiatan penyuluhan yang dilakuan ini merupakan salah satu kegiatan dari sejumlah rangakain kegiatan persiapan atau rintisan wisata desa di Dusun Bulu.

Dasar pemikiran kegiatan bahwa penyuluhan mampu meningkatkan pemahaman partisipan selaku praktisi pariwisata di Dusun Bulu. Oleh karena itu, kegiatan penyuluhan mengenai pelayanan prima ini dipandang penting untuk diberikan terutama bagi masyarakat di destinasi wisata rintisan.

Manfaat praktis dari hasil kegiatan pengabdian masyarakat yang dapat diharapkan adalah : (1) Mampu menambah pemahaman bagi masyarakat yang menjadi partisipan maupun pembaca dalam menciptakan pelayanan yang terbaik bagi wisatawan; (2) Menambah khasanah literatur bagi kalangan akademis mengenai evaluasi program penyuluhan pelayanan prima pada masyarakat pedesaan dan sejauh mana efektifitas dari program penyuluhan seperti ini.

\section{Metode}

Masyarakat Dusun Bulu sedang gencar-gencarnya dalam merintis wisata desa. Oleh karena itu, artikel ini bertujuan untuk membahas program pengabdianberupakegiatanpenyuluhan pelayanan prima. Diikutidengankajianpadasejauh mana program penyuluhan mampu meningkatkan pemahaman partisipan terhadap pelayanan prima dalam pelayanan wisata desa di Dusun Bulu, Desa Jogotirto, Kecamatan Berbah, Kabupaten Sleman, Daerah Istimewa Yogyakarta.

Penyuluhan yang dimaksud adalah kegiatan memberikan pemahaman melalui presentasi materi dengan cara ceramah dan tatap muka antara narasumber dengan partisipan. Narasumber mempresentasikan materi menggunakan media slide power point, dibantu alat bantu LCD proyektor, sedangkan partisipan mendengarkan ceramah hingga selesai. Waktu presentasi yang dialokasikan selama 30 menit.

Subjek yang menjadi partisipan adalah elemen masyarakat yang terlibat dalam inisiasi wisata desa Dusun Bulu yang dipilih secara purposive, dengan mempertimbangkan keterlibatan partisipan dalam inisiasi desa wisata, diantaranya : Kepala Dusun Bulu, Perwakilan Pengurus KKLPMD, Pengurus Wisata, Perwakilan Karang Taruna, dan Perwakilan PKK, sehingga mencapai jumlah total sebanyak 30 partisipan. Dasar penentuan sampel sebanyak 30 partisipan adalah sampel kuota. Penentuan jumlah partisipan juga mempertimbangkan minimnya jumlah masyarakat yang sudah terlibat dalam inisiasi wisata desa, mengingat Dusun Bulu masih merupakan wisata rintisan dan baru beberapa kali menjalankan event.

Objek kegiatan yang evaluasi adalah "pelayanan prima" dengan item-item pertanyaan mencakup 5 dimensi pelayanan prima sesuai penelitian terdahulu yang dilakukan oleh Jaya, 
W dan Rismayanti (2017) meliputi : Bukti langsung (tangibles), kehandalan (reliability), daya tanggap (responsiveness), jaminan (assurance), dan empati (emphaty). Masing-masing diselidiki sebanyak dua kali, yaitu pengetahuan partisipan terhadap 5 dimensi pelayanan prima sebelum dan setelah diadakan penyuluhan.

Data diperoleh dengan menggunakan instrumen kuesionair yang telah didesain sesuai objek penelitian "pelayanan prima" dengan item-item pertanyaan mencakup 5 dimensi pelayanan. Pencarian data dilakukan sebelum dan setelah penyuluhan pada bulan September 2018 sampai bulan Desember 2018.

Analisis data kuantitatif dilakukan melalui uji statistik deskriptif dengan pendekatan persentase, nilai rata-rata (mean) beserta nilai simpangan bakunya (standar deviasi). Metode analisis ini dipilih karena dianggap mampu menggambarkan karakteristik subjek dengan cukup baik. Termasuk pertimbangan pada tingkat kepraktisan penggunaan.

\section{Hasil dan Pembahasan}

\section{Deskripsi Lokasi Pengabdian Masyarakat}

Dusun Bulu secara administratif merupakan bagian dari 10 dusun di wilayah Desa Jogotirto, Kecamatan Berbah, Kapupaten Sleman, Daerah Istimewa Yogyakarta. Dusun-dusun lain yang termasuk dalam wilayah administratif Desa Jogotirto antara lain: Dusun Blambangan, Dusun Jlatren, Dusun Jragung, Dusun Karongan, Dusun Kranggan I, Dusun Kranggan II, Dusun Krasaan, Dusun Rejosari, Dusun Worobangun I.

Batas-batas wilayah Dusun Bulu sebagai berikut: Sebelah Utara berbatasan dengan Dusun Jlatren, sebelah Timur berbatasan langsung dengan Dusun Klampengan, Sebelah Selatan Berbatasan dengan Dusun Kranggan I dan II, sedangkan sebelah barat berbatasan langsung dengan hamparan persawahan yang masuk dalam wilayah Dusun Bulu dan Sentonorejo.

Wilayah Desa Jogotirto pada saat ini telah memiliki daya tarik wisata utama yang sedang dikembangkan dan telah populer di kalangan wisatawan diantaranya: Lava Bantal, Candi Abang, Goa Jepang, Goa Sentono, serta Wisata Petik Buah Jambu Dalhari. Akan tetapi, titik utama persebaran daya tarik wisata tersebut hanya berada di beberapa titik dusun, seperti Dusun Jragung dan Dusun Karongan.

Oleh karena itu, guna meratakan potensi manfaat ekonomi dari kegiatan wisata, maka Dusun Bulu berusaha membuat dan memetakan aktifitas wisata desa di wilayahnya. Namun, hingga saat ini wacana ini masing dalam tahap rintisan dan kajian. Beberapa kali Dusun Bulu memang telah mendapatkan kunjungan wisata pada event-event budaya tahunan seperti pada Upacara Budaya Sadranan. Selain itu, juga pernah diadakan event-event khusus yang sengaja dibuat untuk menarik kunjungan dan partisipasi pihak luar seperti mengadakan lomba lukis anak, jalan sehat dan senam masal.

Jika dikaji lebih dalam, Dusun Bulu Secara ternyata memiliki potensi daya tarik wisata yang sangat lengkap. Beberapa potensi wisata Dusun Bulu dapat dijelaskan sebagai berikut:

1. Potensi daya tarik wisata alam

Dusun Bulu merupakan daerah pedesaan yang masih tergolong alami. Hamparan persawahan yang masih cukup luas dengan pengelolaan semi tradisional mampu menjadikan daya tarik tersendiri bagi calon wisatawan yang berkunjung dan belajar tentang kehidupan desa. Lokasi Dusun Bulu yang diapit pegunungan juga menawarkan pemandangan yang cukup indah.

2. Potensi daya tarik wisata budaya

Dusun bulu memiliki event budaya Merti Dusun yang diselenggarakan tahunan. Merti Dusun merupakan acara budaya yang ditujukan untuk mengekspresikan rasa puja dan puji syukur kepada Tuhan Yang Maha Esa atas rejeki dan keberkahan yang diberikan kepada masyarakat Dusun Bulu.

Selain Merti Dusun, ada juga Upacara Sadranan yang juga diselenggarakan setiap tahun. Upacara Sadranan merupakan upacara budaya yang ditujukan untuk mendoakan keselamatan para leluhur yang telah meninggal. Selain itu Upacara Sadranan memiliki nilai filosofis untuk mengingatkan atas kematian diri yang pasti akan dialami setiap manusia, serta mengingatkan untuk selalu mawas diri untuk hidup lebih baik dan jauh dari dosa. 
Selain event budaya tahunan, Dusun Bulu masih menyimpan kearifan budaya lain yang bernilai luhur, seperti: Upacara Daur Hidup, Malam Tirakatan, Upacara Maulid Nabi Muhammad, dan Karawitan.

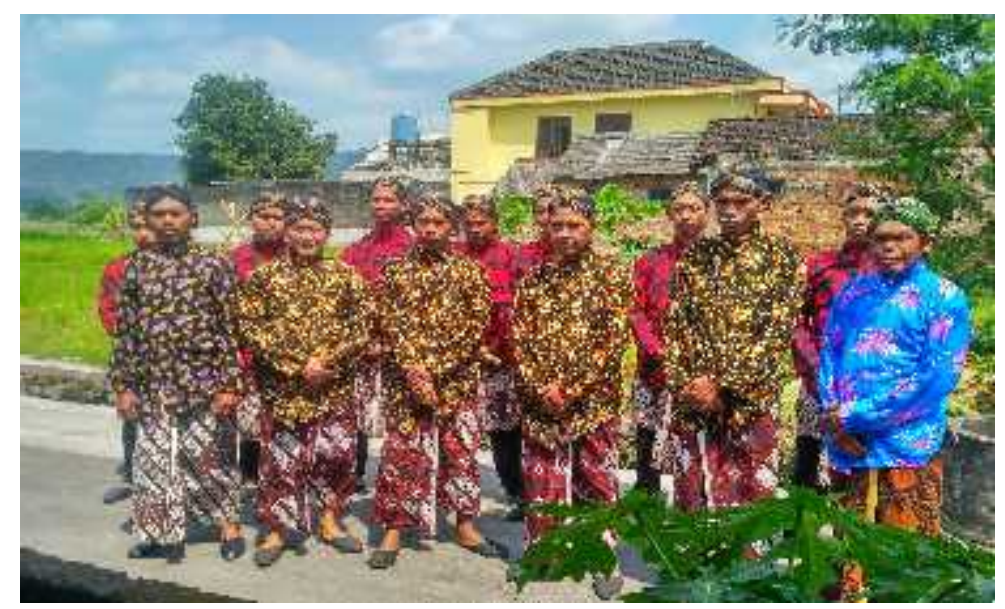

Gambar 1. Peserta Kirab Budaya dari RT 05

3. Potensi daya tarik wisata lainya

Selain potensi alam dan budaya, masih banyak kegiatan lain yang mampu menjadi daya tarik wisata di Dusun Bulu jika dikelola dengan baik. Aktifitas tersebut misalnya: Petik jambu dalhari, belajar kerajinan kulit, belajar membuat kerajinan ukir, wisata kuliner peyek daun kelor, belajar ternak, dan masih banyak lagi potensi lainya.

Untuk mampu menjadi destinasi wisata yang baik diperlukan sumber daya manusia yang ahli dalam mengelolanya, terutama terkait dengan palayanan wisata. Dalam latar belakang telah dijelaskan bahwa pelayanan prima merupakan faktor kunci dari keajuan bisnis pariwisata, bahkan pelayanan prima menjadi faktor yang sangat menentukan apakah suatu destinasi akan berkelanjutan atau tidak. Maka dari itu, kegiatan pengabdian masyarakat ini dinilai perlu untuk meningkatkan kompetensi dan kapasitas masyarakat Dusun Bulu.

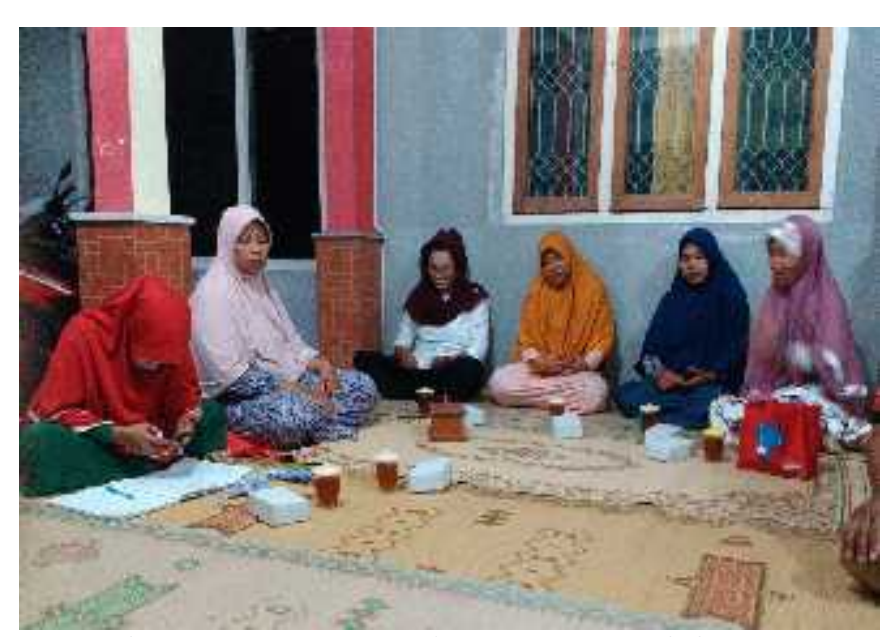

Gambar 2. Foto peserta kegiatan pengabdian

\section{Hasil Analisis Deskriptif}

Hasil penyuluhan pelayanan prima yang telah dilakukan dengan pendekatan 5 dimensi pelayanan secara makro menunjukan hasil sebagai berikut : 


\section{Tabel 1}

Ouput Analisis Deskriptif tentang Pemahaman Pelayanan Prima

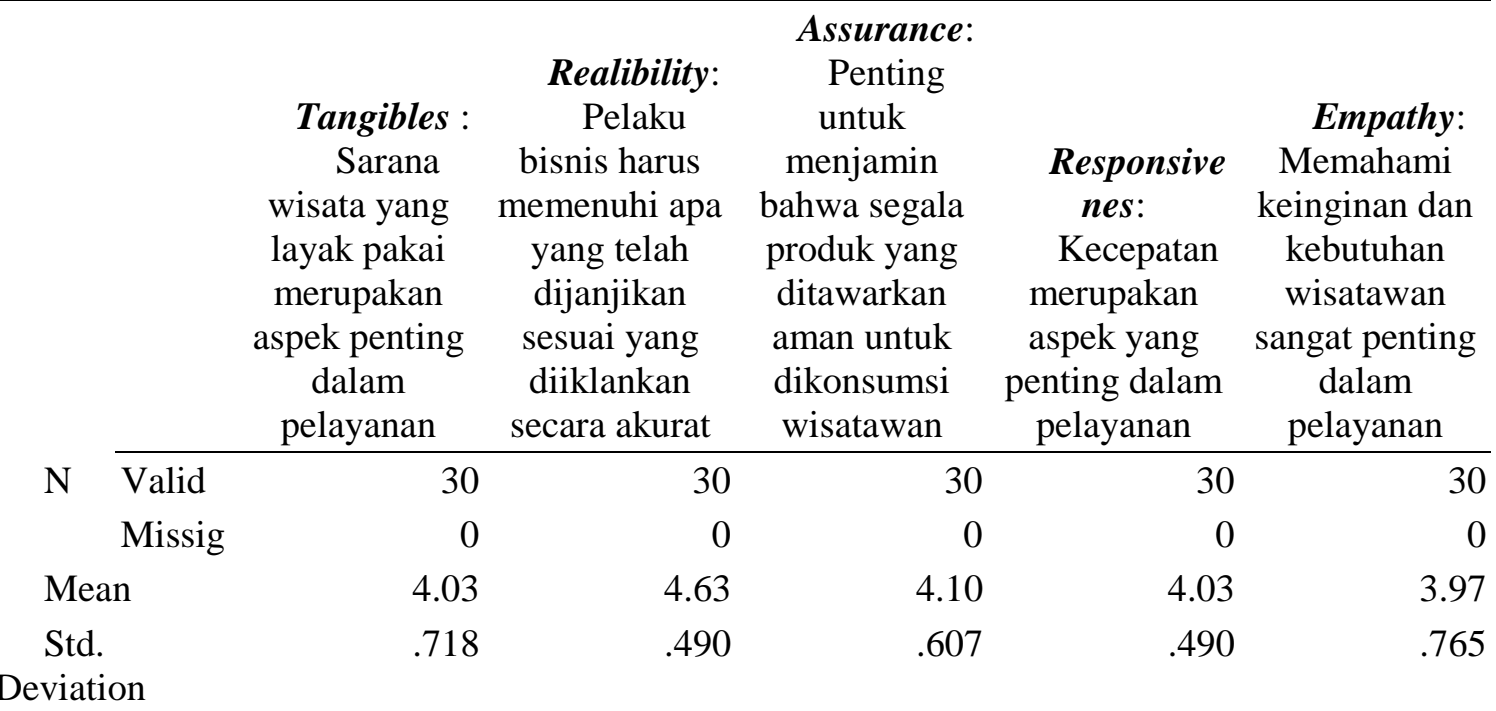

Sumber: Hasil olah data dengan soware SPSS 14

Hasil analisis deskriptif pada tabel 1 hasil output analisis deskriptif diatas menujukan bahwa secara makro nilai rata-rata berada pada rentang 3,97 sampai 4,63, dengan nilai standar deviasinya antara 0,490 sampai 0,765 yang berarti bahwa yang jika di semua dibulatkan maka makna kualitatif dari penilaian partisipan terhadap semua faktor dalam dimensi pelayanan prima adalah setuju.

Hasil analisis di atas mampu membuktikan bahwa partisipan mampu memiliki pemahaman yang baik setelah penyuluhan dilakukan. Dengan ini dapat disimpulkan bahwa menurut partisipan pengelolaan pelayanan prima dalam pariwisata sangat penting guna mewujudkan pelayanan pariwisata yang baik. Selanjutnya pendapat partisipan terhadap masing-masing faktor dijelaskan dengan menggunakan pendekatan prosentase sebegai berikut:

1. Bukti Langsung (Tangibles)

Hasil analisis tanggapan partisipan terhadap faktor bukti langsung (reliability) disajikan dalam tabel 2 berikut:

Tabel 2

\begin{tabular}{|c|c|c|c|c|c|}
\hline \multicolumn{6}{|c|}{$\begin{array}{l}\text { Sarana wisata yang layak pakai merupakan aspek penting } \\
\text { dalam pelayanan }\end{array}$} \\
\hline & & Frequency & Percent & $\begin{array}{c}\text { Valid } \\
\text { Percent }\end{array}$ & $\begin{array}{c}\text { Cumulative } \\
\text { Percent }\end{array}$ \\
\hline \multirow[t]{4}{*}{ Valid } & Netral & 7 & 23.3 & 23.3 & 23.3 \\
\hline & Setuju & 15 & 50.0 & 50.0 & 73.3 \\
\hline & $\begin{array}{l}\text { Sangat } \\
\text { Setuju }\end{array}$ & 8 & 26.7 & 26.7 & 100.0 \\
\hline & Total & 30 & 100.0 & 100.0 & \\
\hline
\end{tabular}

Sumber: Hasil olah data dengan soware SPSS 14

Hasil analisis deskriptif pada tabel 2 hasil diatas menujukan bahwa sebanyak 15 persen partisipan setuju dan 8 persen sangat setuju terhadap pernyataan "Sarana wisata yang layak pakai merupakan aspek penting dalam pelayanan." Sisanya hanya sebanyak 7 persen responden yang bersikap netral, serta tidak ada partisipan 0 persen yang berpendapat negatif (tidak setuju atau sangat tidak setuju).

Hasil analisis di atas mampu membuktikan bahwa setelah penyuluhan dilakukan partisipan mampu memiliki pemahaman yang baik bahwa bukti langsung dalam pelayanan pariwisata sangat penting untuk dikelola untuk mewujudkan pelayanan pariwisata yang terbaik. 
2. Kehandalan(Realibility)

Hasil analisis tanggapan partisipan terhadap faktor kehandalan(realibility) disajikan dalam tabel 3 berikut:

Tabel 3

Pelaku bisnis harus memenuhi apa yang telah dijanjikan sesuai yang diiklankan secara akurat

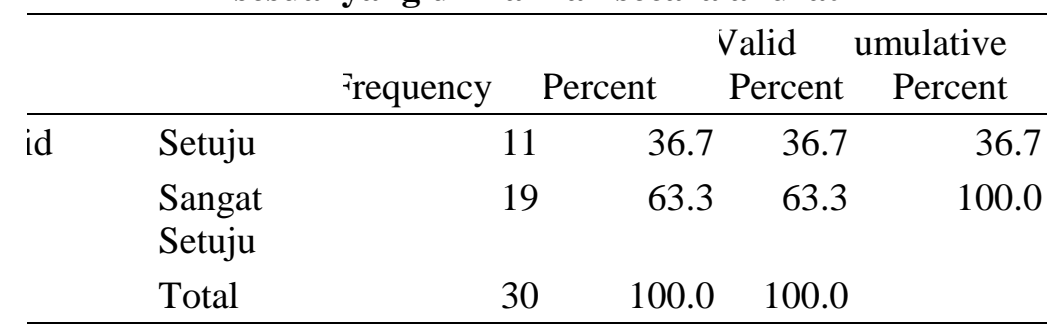

Sumber: Hasil olah data dengan soware SPSS 14

hasil analisis deskriptif tabel 3 diatas menujukan bahwa sebanyak 11 persen partisipan setuju dan 19 persen sangat setuju terhadap pernyataan "Pelaku bisnis harus memenuhi apa yang telah dijanjikan sesuai yang diiklankan secara akurat." Sisanya tidak ada partisipan 0 persen yang bersikap negatif (tidak setuju atau sangat tidak setuju). Hasil diatas analisis diatas mampu membuktikan bahwa setelah penyuluhan dilakukan partisipan mampu memiliki pemahaman yang baik bahwa kehandalan(realibility) dalam pelayanan pariwisata sangat penting untuk dikelola dengan baik.

3. Jaminan (Assurance)

Hasil analisis tanggapan partisipan terhadap faktor jaminan (assurance) disajikan dalam tabel 4 berikut:

Tabel 4

\begin{tabular}{rlrrrr}
\hline \multicolumn{3}{c}{$\begin{array}{c}\text { Penting untuk menjamin bahwa segala produk yang } \\
\text { ditawarkan aman untuk dikonsumsi wisatawan }\end{array}$} \\
\hline & & \multicolumn{4}{c}{$\begin{array}{c}\text { Valid } \\
\text { Percen Cumulative }\end{array}$} \\
& & Frequency & Percent & t & Percent \\
\hline Valid & Netral & 4 & 13.3 & 13.3 & 13.3 \\
& Setuju & 19 & 63.3 & 63.3 & 76.7 \\
& Sangat & 7 & 23.3 & 23.3 & 100.0 \\
& Setuju & & & & \\
& Total & 30 & 100.0 & 100.0 & \\
\hline
\end{tabular}

Sumber: Hasil olah data dengan soware SPSS 14

Hasil analisis deskriptif pada tabel 4 diatas menujukan bahwa mayoritas partisipan atau sebanyak 19 persen partisipan setuju dan 7 persen sangat setuju terhadap pernyataan "Penting untuk menjamin bahwa segala produk yang ditawarkan aman untuk dikonsumsi wisatawan." sisanya sebanyak 4 persen responden bersikap netral, Sisanya tidak ada partisipan 0 persen yang bersikap negatif (tidak setuju atau sangat tidak setuju). Hasil diatas analisis diatas membuktikan bahwa setelah penyuluhan dilakukan partisipan mampu memiliki pemahaman yang baik bahwa jaminan (assurance) dalam pelayanan pariwisata sangat penting untuk dikelola dengan baik.

4. Daya Tanggap (Responsiveness)

Hasil analisis tanggapan partisipan terhadap faktor daya tanggap (responsiveness) disajikan dalam tabel berikut: 
Tabel 5

\begin{tabular}{|c|c|c|c|c|c|}
\hline \multicolumn{6}{|c|}{ Kecepatan merupakan aspek yang penting dalam pelayanan } \\
\hline & & & \multicolumn{3}{|c|}{ Valid } \\
\hline & & & & Percen & Cumulative \\
\hline & & Frequency & Percent & $\mathrm{t}$ & Percent \\
\hline \multirow[t]{4}{*}{ Valid } & Netral & 3 & 10.0 & 10.0 & 10.0 \\
\hline & Setuju & 23 & 76.7 & 76.7 & 86.7 \\
\hline & $\begin{array}{l}\text { Sangat } \\
\text { Setuju }\end{array}$ & 4 & 13.3 & 13.3 & 100.0 \\
\hline & Total & 30 & 100.0 & 100.0 & \\
\hline
\end{tabular}

Sumber: Hasil olah data dengan soware SPSS 14

Hasil analisis deskriptif pada tabel 5 diatas menujukan bahwa mayoritas partisipan bersikap positif atau sebanyak 23 persen setuju dan 4 persen sangat setuju terhadap pernyataan "Kecepatan merupakan aspek yang penting dalam pelayanan." Sedangkan nilai netral sebanyak 3 persen. Tidak ada partisipan 0 persen yang berpendapat negatif.

Hasil diatas analisis diatas membuktikan bahwa setelah penyuluhan dilakukan partisipan mampu memiliki pemahaman yang baik bahwa daya tanggap (responsiveness) dalam pelayanan pariwisata sangat penting untuk dikelola dengan baik.

5. Empati (Empathy)

Hasil analisis tanggapan partisipan terhadap faktor empati disajikan dalam tabel 6 berikut:

Tabel 6

Memahami keinginan dan kebutuhan wisatawan sangat penting dalam pelayanan

\begin{tabular}{rlrrrr}
\hline & & \multicolumn{3}{c}{ Valid } \\
& & Frequency & Percent & \multicolumn{1}{c}{ t } & Percent \\
\hline \multirow{2}{*}{ Valid } & Netral & 9 & 30.0 & 30.0 & 30.0 \\
& Setuju & 13 & 43.3 & 43.3 & 73.3 \\
& Sangat & 8 & 26.7 & 26.7 & 100.0 \\
& Setuju & & & & \\
& Total & 30 & 100.0 & 100.0 & \\
\hline
\end{tabular}

Sumber: Hasil olah data dengan soware SPSS 14

Berdasarkan hasil analisis deskriptif pada tabel 6 diatas. Terlihat bahwa sebanyak 13 persen partisipan setuju dan 8 persen sangat setuju terhadap pernyataan "Memahami keinginan dan kebutuhan wisatawan sangat penting dalam pelayanan." sikap netral sebanyak 9 persen dan tidak ada partisipan 0 persen yang bersikap negatif (tidak setuju atau sangat tidak setuju).

Hasil diatas analisis diatas membuktikan bahwa setelah penyuluhan dilakukan partisipan mampu memiliki pemahaman yang baik bahwa empati dalam pelayanan pariwisata sangat penting untuk dikelola dengan baik.

\section{Simpulan}

Kegiatan penyuluhan pelayanan prima yang telah dilakukan dengan pendekatan 5 dimensi pelayanan menunjukan hasil yang cukup baik, yaitu berupa pemahaman partisipan yang baik terhadap masing-masing dimensi pelayanan prima, diantaranya : (1) Pemahaman partisipan yang baik terhadap dimensi reliability dalam pelayanan wisata desa; (2) Pemahaman partisipan yang baik terhadap dimensi assurance dalam pelayanan wisata desa; (3) 
Pemahaman partisipan yang baik terhadap dimensi responsiveness dalam pelayanan wisata desa; (4) Pemahaman partisipan yang baik terhadap dimensi empathy dalam pelayanan wisata desa; (5) Pemahaman partisipan yang baik terhadap pemahaman dimensi tangible dalam pelayanan wisata desa.

Keterbatasan metode penyuluhan yang dibahas dalam artikel ini, beserta keterbatasan waktu dan teknik analisis data, tentu juga menghasilkan pembahasan yang memiliki banyak kekurangan. Keterbatasan teknik analisis data terletak pada ketidakmampuanya dalam membuktikan pemahaman partisipan terhadap pelayanan prima yang seutuhnya terjadi. Apakah dengan pemahaman partisipan yang baik juga akan berjalan selaras dengan peningkatan skill dan perilaku partisipan dalam memberikan pelayanan pariwisata. Apakah pelayanan yang terjadi akan menjadi semakin baik atau tidak.

Oleh karena itu, artikel ini memberi rekomendasi kepada untuk melakukan kegiatanpengabdiandiikutidenganevaluasiyang lebihmendalam, denganmengandalkan pengamatan perilaku diharapkan mampu diperoleh data-data yang lebih kompleks dan valid mengenai peningkatan perilaku partisipan dalam memberikan pelayanan pariwisata. Pengabdian masyarakat yang selanjutnya juga sangat disarankan untuk memberikan pelatihan berbasis pada peningkatan skill melalui pelatihan-pelatihan keterampilan seperti: (1) Senyum, salam, sapa (3S); (2) Tata cara penanganan keluhan pelanggan; (3) Etika pelayanan; dan lain sebagainya.

\section{Referensi}

Al Rasyid, H. (2017). Pengaruh Kualitas Layanan dan Pemanfaatan Teknologi terhadap Kepuasan dan Loyalitas Pelanggan Go-Jek. Jurnal Ecodemica: Jurnal Ekonomi, Manajemen, dan Bisnis, 1(2), 210-223.

Buletin Dewata. (2017). Mengatasi Keluhan Negatif Wisatawan terhadap DTW Bali. Retrieved December 17, 2018, from http://www.buletindewata.com/beritadaerah/2017/06/22/1634

Edvardsson, B., Gustafsson, A., \& Roos, I. (2005). Service Portraits in Service Research: a Critical Review. International Journal of Service Industry Management, 16(1), 107-121.

González, M. E. A., Comesaña, L. R., \& Brea, J. A. F. (2007). Assessing Tourist Behavioral Intentions through Perceived Service Quality and Customer Satisfaction. Journal of Business Research, 60(2), 153-160.

Hermawan, H. (2017). Pengaruh Daya Tarik Wisata, Keselamatan dan Sarana Wisata Terhadap Kepuasan serta Dampaknya terhadap Loyalitas Wisatawan : Studi Community Based Tourism di Gunung Api Purba Nglanggeran. Wahana Informasi Pariwisata : Media Wisata, 15(1), 562-577.

Hermawan, H., Brahmanto, E., \& Hamzah, F. (2018). Pengantar Manajemen Hospitality. Pekalongan: Penerbit NEM.

Jaya, I. M. S. A., Wahyuni, L. M., \& Rismayanti, A. (2017). Penerapan Pelayanan Prima untuk Meningkatkan Kepuasan Konsumen Golf pada Nirwana Bali Golf Club. Jurnal Bisnis Dan Kewirausahaan, 12(3 November), 206.

Kamus Besar Bahasa Indonesia (KBBI). (2018). Retrieved December 17, 2018, from https://kbbi.web.id/suluh

Karsidi, R. (2001). Paradigma Baru Penyuluhan Pembangunan dalam Pemberdayaan Masyarakat. MediaTor (Jurnal Komunikasi), 2(1), 115-125.

Kotler, P., \& Armstrong, G. (2012). Principles of Marketing, 14e.New Jersey, USA: PearsonEducation Ltd.

Ralemug, T. (2018). Terancam Matinya Area Pariwisata Pantai Anyer, Carita, dan Karang Bolong di Banten karena Tarif Parkir dan Harga Makanan yang Tidak Ramah. Jurnal Studi Desain, 1(2), 47-51. 
Sadnyari, I. A. M. (2017). Viral, Pembeli di Lesehan Malioboro Kaget Disodori Nota Harga, Mana yang Tidak Masuk Akal? Retrieved September 12, 2018, from http://bali.tribunnews.com/2017/09/12/viral-pembeli-di-lesehan-malioboro-kagetdisodori-nota-harga-mana-yang-tidak-masuk-akal?page=all

Santosa. (2016). Statistika Hospitalitas. Yogyakarta: Deepublish.

Sulastiyono, A. (2011). Manajemen Penyelenggaraan Hotel: Seri Manajemen Usaha Jasa Sarana Pariwisata dan Akomodasi. Bandung: Alfabeta.

Wilson, A., Zeithaml, V. A., Bitner, M. J., \& Gremler, D. D. (2012). Services Marketing: Integrating Customer Focus Across the Firm. McGraw Hill.

Yang, F., \& Zhang, H. (2018). The Impact of Customer Orientation on New Product Development Performance: The Role of Top Management Support. International Journal of Productivity and Performance Management, 67(3), 590-607. 